\title{
EFFECT OF PREOPERATIVE MAGNESIUM INFUSION ON POSTOPERATIVE PAIN IN PATIENTS UNDER GENERAL ANAESTHESIA
}

\author{
Nidhin ${ }^{1}$, Abraham A. A2 \\ ${ }_{1}^{1}$ Post Graduate, Department of Anaesthesia, Yenepoya Medical College, Mangalore. \\ 2 Professor, Department of Anaesthesia, Yenepoya Medical College, Mangalore.
}

\begin{abstract}
Despite the availability of newer clinical practice objectives, effective analgesics and new technologies for pain measurement, the management of postoperative pain continues to remain a problem. Patients have the right to be recognized as experts of their own pain experience and to have their pain report reflected accurately in the type of pain relief they receive. They also have the right to expect that relief of their pain be considered to be a reasonable goal of the treatment. With the increasing understanding of pain physiology and the (N-Methyl D Aspartate) NMDA receptor, the use of Magnesium for secondary analgesia and as an adjuvant to different regimens is introducing newer possibilities for the use of Magnesium in acute and chronic pain. The popularity of Magnesium sulphate in wide spectrum of clinical application also finds its use in attenuating postoperative pain. In our study, we will be assessing the patients while they are undergoing surgery and their postoperative pain scores when the patient is premedicated with Magnesium sulphate.
\end{abstract}

\section{MATERIALS AND METHODS}

60 patients undergoing general surgery were randomly divided into 2 groups of 30 each. The Magnesium sulphate group received $50 \mathrm{mg} / \mathrm{kg}$ in $100 \mathrm{~mL}$ of normal saline solution over 30 minutes before the surgery intravenously, whereas control group received same volume of normal saline solution over 30 minutes preoperatively.

\section{RESULTS}

Data collected was subjected to standard statistical analysis and analysed using Chi-square test. There was significant difference in the pain scores after the injection of Magnesium sulphate between both the groups.

\section{CONCLUSION}

We found out that majority of patients find relief, while a minority of patients had the issue of nausea and vomiting. We conclude that Magnesium sulphate provides a good pain relief without any significant adverse effects.

\section{KEYWORDS}

Magnesium Sulphate, Postoperative Pain, Rescue Analgesia, Visual Analogue Scale.

HOW TO CITE THIS ARTICLE: Nidhin, Abraham AA. Effect of preoperative magnesium infusion on postoperative pain in patients under general anaesthesia. J. Evolution Med. Dent. Sci. 2016;5(17):838-841, DOI: 10.14260/jemds/2016/194

\section{INTRODUCTION}

Inadequate pain relief in the postoperative phase is a wellknown problem worldwide. A lot of surveys over a long time show that many patients still suffer from moderate-to-severe postoperative pain; poorly managed pain may interfere with postoperative complications, cause patient suffering and prolong recovery. Although pain is predictable after surgery, all efforts should be made primarily to minimize acute pain and secondly to prevent persistent pain. Patients with good analgesia are more co-operative, recover more rapidly and leave hospital sooner. Preoperative administration of drugs to relieve the postoperative pain is known as preventive analgesia. Preventive analgesia can be done by relieving the anxiety preoperatively, administration of regional blocks, use of opioids, NSAIDS, alpha-2 adrenergic agonists and various other drugs.

Financial or Other, Competing Interest: None.

Submission 13-01-2016, Peer Review 10-02-2016,

Acceptance 15-02-2016, Published 27-02-2016.

Corresponding Author:

Dr. Abraham A. A,

Professor, Department of Anaesthesia,

Yenepoya Medical College,

Mangalore.

E-mail: abraham3aby@gmail.com

DOI: $10.14260 /$ jemds/2016/194
Magnesium sulphate is popularly used as an anticonvulsant, antiarrhythmic and also it has got analgesic properties. Administration of Magnesium sulphate to relieve postoperative pain is not used routinely, even though there are few studies which mentions its use for postoperative analgesia. To relieve postoperative pain, multimodal analgesia therapy is always superior to a single drug.

Present study is undertaken to know whether the administration of $50 \mathrm{mg} / \mathrm{kg}$ of Magnesium sulphate along with $2 \mathrm{mcg} / \mathrm{kg}$ of fentanyl has any beneficial effect over other combination of drugs, which is routinely used in the daily practice. Magnesium, also called "Nature's physiological calcium channel blocker" has anti-nociceptive effects in animals and potentiates the analgesic effects of morphine in patients with chronic pain. Magnesium is also an antagonist of the N-methyl-D-aspartate (NMDA) receptor ion channel and this may explain part of its analgesic activity.

Magnesium also has a vasodilatory effect mediated by endothelium-derived nitric oxide. Nitric oxide donors protect vascular endothelium from ischemia and reperfusionmediated endothelial dysfunction. This mechanism might also explain the ability of Magnesium to reduce pain. 


\section{METHODOLOGY}

After ethical committee approval and informed consent, 60 patients belonging to "American society of Anaesthesiology" (ASA) grade II and I, aged between 18 to 65 years, scheduled for elective surgery under general anaesthesia were selected and divided randomly using computer generated tables into two groups 30 patients each; $2 \mathrm{mcg} / \mathrm{kg}$ of intravenous fentanyl was administered to both the groups before induction of general anaesthesia. The study was conducted in the time span from October 2013 to September 2015. Thorough preanaesthetic evaluation and routine investigation were carried out before taking up the patient for surgery. Patients were explained regarding the visual analogue scale during the preanaesthetic evaluation. All the patients in our study were done under general anaesthesia. They underwent routine investigations and good rapport was established with the patient to alleviate anxiety. Uniform premedication and monitoring were instituted in all patients. A specially designed proforma was used to collect the data, which included patient's particulars, indication for surgery, the anaesthetic details, intra-operative monitoring, observation for side effects, etc. Sample size was calculated using Two sample $\mathrm{T}$ test power analysis.

Patients were randomly assigned to one of two groups, either receiving 50\% Magnesium sulphate (Group M) or receiving normal saline as placebo (Group P). After instituting standard monitoring (Electrocardiogram lead II, non-invasive arterial blood pressure and pulse oximetry), an 18-gauge cannula was inserted into the forearm vein with IV fluid on flow. Patients in Group $M$ received intravenous 50\% Magnesium sulphate $2 \mathrm{~mL}$ diluted in $100 \mathrm{~mL}$ of saline 30 minutes prior to administering general anaesthesia. Patients in the Placebo group (Group P) received $100 \mathrm{~mL}$ of $0.9 \%$ normal saline 30 minutes prior to administering general anaesthesia. Pain at emergence from anaesthesia and 1, 4, 8, 12 hours after surgery was evaluated using a $0-10 \mathrm{~cm}$ VAS. During the first 4 hours the patients were kept in the recovery room and rescue analgesia provided at VAS $>$ or equal to score 3 in the form of Fentanyl $(1-2 \mathrm{mcg} / \mathrm{kg})$. Thereafter the patients were sent to the ward and Diclofenac sodium was given intramuscularly on demand.

\section{RESULTS}

\begin{tabular}{|c|c|c|c|c|c|}
\hline & \multicolumn{2}{|c|}{ GROUP } & \multirow[b]{2}{*}{ Total } \\
\hline & & & $\begin{array}{c}\text { MAGNESIUM } \\
\text { SULPHATE }\end{array}$ & $\begin{array}{c}\text { PLACEBO } \\
\text { GROUP }\end{array}$ & \\
\hline \multirow{8}{*}{$\begin{array}{c}\mathrm{A} \\
\mathrm{GE}\end{array}$} & \multirow[b]{2}{*}{$<=20$} & Count & 3 & 1 & 4 \\
\hline & & $\begin{array}{c}\quad \% \\
\text { within } \\
\text { group }\end{array}$ & $9.7 \%$ & $2.6 \%$ & $5.8 \%$ \\
\hline & \multirow[b]{2}{*}{$21-30$} & Count & 5 & 7 & 12 \\
\hline & & $\begin{array}{c}\quad \% \\
\text { within } \\
\text { group }\end{array}$ & $22.6 \%$ & $23.7 \%$ & $23.2 \%$ \\
\hline & \multirow[b]{2}{*}{$31-40$} & Count & 7 & 2 & 9 \\
\hline & & $\begin{array}{c}\quad \% \\
\text { within } \\
\text { group }\end{array}$ & $22.6 \%$ & $13.2 \%$ & $17.4 \%$ \\
\hline & \multirow[b]{2}{*}{$41-50$} & Count & 4 & 8 & 12 \\
\hline & & $\begin{array}{c}\quad \% \\
\text { within } \\
\text { group }\end{array}$ & $22.6 \%$ & $21.1 \%$ & $21.7 \%$ \\
\hline
\end{tabular}

\begin{tabular}{|c|c|c|c|c|}
\hline \multirow[b]{2}{*}{$51-60$} & Count & 4 & 8 & 12 \\
\hline & $\begin{array}{c}\% \\
\text { within } \\
\text { group }\end{array}$ & $12.9 \%$ & $21.1 \%$ & $17.4 \%$ \\
\hline \multirow[b]{2}{*}{$>60$} & Count & 3 & 4 & 7 \\
\hline & $\begin{array}{c}\% \\
\text { within } \\
\text { group }\end{array}$ & $9.7 \%$ & $10.5 \%$ & $10.1 \%$ \\
\hline \multirow[b]{2}{*}{22.00} & Count & 1 & 1 & 2 \\
\hline & $\begin{array}{c}\% \\
\text { within } \\
\text { group }\end{array}$ & $0.0 \%$ & $2.6 \%$ & $1.4 \%$ \\
\hline \multirow[b]{2}{*}{33.00} & Count & 0 & 2 & 2 \\
\hline & $\begin{array}{c}\% \\
\text { within } \\
\text { group }\end{array}$ & $0.0 \%$ & $5.3 \%$ & $2.9 \%$ \\
\hline \multirow[b]{2}{*}{ Total } & Count & 30 & 30 & 60 \\
\hline & $\begin{array}{c}\% \\
\text { within } \\
\text { GROUP }\end{array}$ & $100.0 \%$ & $100.0 \%$ & $100.0 \%$ \\
\hline \multicolumn{5}{|c|}{ Table 1: Age * Group Cross-Tabulation } \\
\hline
\end{tabular}

The study was carried out in Yenepoya Medical College from October 2013 to September 2015 on 60 patients of ASA Grade 1 and 2 undergoing general anaesthesia.

As shown in Table 1, the majority of patients were in the age group of 21 years to 50 years. The difference in age between both groups is not statistically significant. The ordinal and categorical data (VAS scores and sedation score) is analysed by Chi square test and was found out not to be significant.

\begin{tabular}{|c|c|c|c|c|c|}
\hline & \multicolumn{2}{|c|}{ GROUP } & \multirow[b]{2}{*}{ Total } \\
\hline & & & $\begin{array}{l}\text { MAGNESIUM } \\
\text { SULPHATE }\end{array}$ & $\begin{array}{c}\text { PLACEBO } \\
\text { GROUP }\end{array}$ & \\
\hline \multirow{4}{*}{ SEX } & \multirow[b]{2}{*}{$\mathrm{F}$} & Count & 15 & 15 & 30 \\
\hline & & $\begin{array}{l}\% \text { within } \\
\text { group }\end{array}$ & $50.0 \%$ & $50.0 \%$ & $50.0 \%$ \\
\hline & \multirow[b]{2}{*}{ M } & Count & 15 & 15 & 30 \\
\hline & & $\begin{array}{l}\text { \% within } \\
\text { group }\end{array}$ & $50.0 \%$ & $50.0 \%$ & $50.0 \%$ \\
\hline \multirow{2}{*}{\multicolumn{2}{|c|}{ Total }} & Count & 30 & 30 & 60 \\
\hline & & $\begin{array}{c}\begin{array}{c}\% \text { within } \\
\text { group }\end{array} \\
\end{array}$ & $100.0 \%$ & $100.0 \%$ & $100.0 \%$ \\
\hline
\end{tabular}

As shown in Table 2, the total number of female patients receiving Magnesium sulphate was found out to be 15 (50.0\%) compared to the females who received placebo was 15 $(50.0 \%)$. The total number of male patients receiving Magnesium sulphate was found out to be $15,50.0 \%$ compared to the males, who received placebo which was $15(-50.0 \%)$. The total number of male patients, which was included for this study was 30 patients. The data was analysed by Chi square test and $\mathrm{p}$ was found out to be .894 and was not statistically significant. 


\begin{tabular}{|c|c|c|c|c|c|c|c|}
\hline & GROUP & $\mathbf{N}$ & Mean & $\begin{array}{c}\text { Std. } \\
\text { Deviation }\end{array}$ & $\mathbf{t}$ & df & P VALUE \\
\hline \multirow{2}{*}{ 1ST HOUR } & MAGNESIUM SULPHATE & 31 & 1.48 & 0.724 & \multirow{2}{*}{-8.53} & \multirow{2}{*}{67} & \multirow{2}{*}{$<0.001$} \\
\hline & PLACEBO & 38 & 2.95 & 0.695 & & & \\
\hline \multirow{2}{*}{ 4TH HOUR } & MAGNESIUM SULPHATE & 31 & 2.55 & 0.723 & \multirow{2}{*}{-9.03} & \multirow{2}{*}{50.67} & \multirow{2}{*}{$<0.001$} \\
\hline & PLACEBO & 38 & 3.92 & 0.487 & & & \\
\hline \multirow{2}{*}{ 8TH HOUR } & MAGNESIUM SULPHATE & 31 & 3.23 & 0.956 & \multirow{2}{*}{-8.06} & \multirow{2}{*}{67} & \multirow{2}{*}{$<0.001$} \\
\hline & PLACEBO & 38 & 5 & 0.87 & & & \\
\hline \multirow{2}{*}{ 12TH HOUR } & MAGNESIUM SULPHATE & 31 & 4.55 & 1.028 & \multirow{2}{*}{-8.51} & \multirow{2}{*}{67} & \multirow{2}{*}{$<0.001$} \\
\hline & PLACEBO & 38 & 6.63 & 0.998 & & & \\
\hline \multirow[b]{2}{*}{ SEDATION SCORE } & MAGNESIUM SULPHATE & 31 & 1.06 & 0.25 & \multirow[b]{2}{*}{1.438} & \multirow[b]{2}{*}{30} & \multirow[b]{2}{*}{0.161} \\
\hline & $\begin{array}{l}\text { NO MAGNESIUM } \\
\text { SULPHATE }\end{array}$ & 38 & 1 & 0 & & & \\
\hline
\end{tabular}

Table 3: Visual Analogue Score 4

Table 3 shows the Visual Analogue Score (VAS) of the patients recorded at 1 hour, 4 hours, 8 hours and 12 hours and sedation score. In patients who were administered with Magnesium sulphate Visual analogue scale was found to be of $\mathrm{p}$ value less than 0.001 and was significant. The patients receiving placebo was having a standard deviation of 2.95 in the $1^{\text {st }}$ hour. The patients were assessed with the pain scale in the $12^{\text {th }}$ hour and it was found out to be significant revealing that there was good relief for the patients who were on Magnesium sulphate.

\begin{tabular}{|c|c|c|c|c|c|}
\hline & & & \multicolumn{2}{|l|}{ GROUP } & \multirow{2}{*}{ Total } \\
\hline & & & MAGNESIUM SULPHATE & PLACEBO & \\
\hline \multirow{4}{*}{$\begin{array}{l}\text { RESCUE } \\
\text { ANALGESIA }\end{array}$} & \multirow{2}{*}{ NO } & Count & 18 & 2 & 20 \\
\hline & & $\%$ within group & $64.5 \%$ & $5.3 \%$ & $31.9 \%$ \\
\hline & \multirow{2}{*}{ YES } & Count & 10 & 30 & 40 \\
\hline & & $\%$ within group & $35.5 \%$ & $94.7 \%$ & $68.1 \%$ \\
\hline \multirow{2}{*}{\multicolumn{2}{|c|}{ Total }} & Count & 30 & 30 & 60 \\
\hline & & \% within group & $100.0 \%$ & $100.0 \%$ & $100.0 \%$ \\
\hline
\end{tabular}

The rescue analgesia provided was fentanyl $1-2 \mathrm{mcg} / \mathrm{kg}$. As shown in Table 4, rescue analgesia provided in the placebo group was for 30 patients with a percentage of $94.7 \%$ and in the Magnesium group the number of patients who were administered with rescue analgesia was 10 , totally comprising about 40 patients. The rescue analgesia was not provided in 20 patients of both the groups.

The Chi-square test was found to be not significant.

The rescue analgesia provided to the Magnesium sulphate group was comparatively lesser when compared to the placebo group.

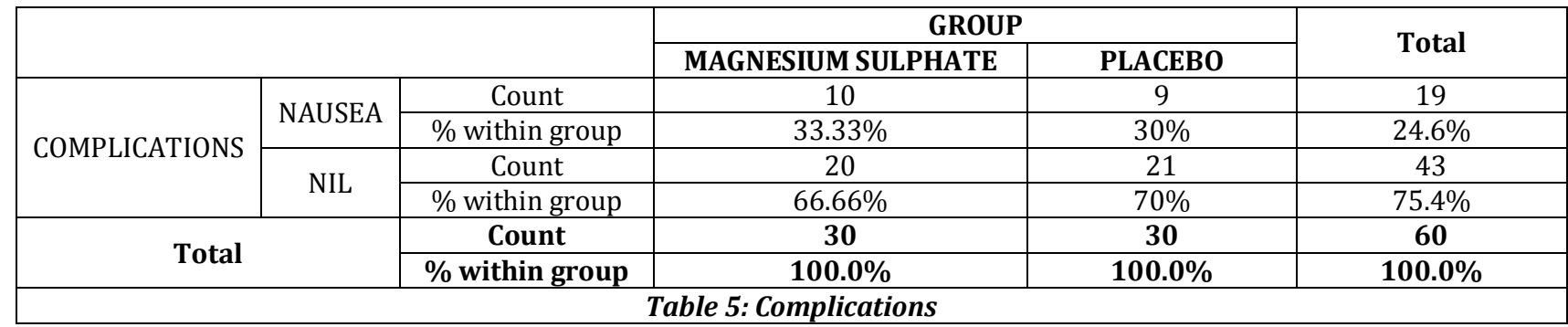

As shown in Table 6, complication or the adverse effects we encountered during this study in the Magnesium group were primarily nausea and vomiting in the patients after the administration of intravenous Magnesium sulphate group. Approximately, 10 patients in Magnesium sulphate group had nausea and 2 patients had an episode of vomiting, 7 patients in the placebo group had the nausea episode. The complications were analysed with Chi square test and were found to be 0.720 and are not significant.

\section{DISCUSSION}

Magnesium sulphate has various clinical uses of which alleviating pain postoperatively is one. The mechanism of the analgesic effect of Magnesium is not very clear, but interference with calcium channels and NMDA receptors may play a role. Magnesium acts as a non-competitive inhibitor of the inositol 1, 4, 5-triphosphate (IP3)-gated calcium channel and of IP3 binding. Thus, it acts as an intracellular calcium antagonist acting at IP3 sensitive calcium release channels. The analgesic action of some calcium channel blockers is known to be due to an increase of the nociceptive threshold resulting from interference with calcium influx, Magnesium paves way for blocking the NMDA receptor currents in a voltage-dependent manner by blocking the receptor channel. We conducted this study with 60 patients undergoing general surgery where they would be randomly divided into 2 groups of 30 each.

In the various studies across the world the usage of Magnesium sulphate has gained popularity considering its availability and cost effectiveness. Kiran and Gupta. ${ }^{1}$ did a similar study and utilised $50 \mathrm{mg} / \mathrm{kg}$ of Magnesium and explained about the pain relief and the effectiveness in the 
postoperative pain relief. Most of the time the observed a Visual analogue scale of less than 3 in the first 8 hours' duration, while some of the authors. ${ }^{2}$ who utilised morphine had a pain relief for more than 24 hours.

In a study done by Dabbagh. ${ }^{3}$ he had used a very low dose of Magnesium sulphate $(8 \mathrm{mg} / \mathrm{kg})$ and obtained pain relief for more than 24 hours as he had used Morphine, which has a much more pain relief and does not correlate to the magnesium advantage in that study. In our study group, we had a VAS score of 1.5, 2.5, 4 and 4.5 at the 1-hour, $4^{\text {th }}$ hour, $8^{\text {th }}$ hour and $12^{\text {th }}$ hour which indicates the patient had good pain relief up to 8 hours postoperatively and in the placebo group the VAS score was 3, 4, 5 and 6.5 which indicates the patient in the control group has pain relief up to only 4 hours. The VAS score of both the groups were above 4.5, which indicate they have pain after 12 hours. The placebo group had pain relief for only 4 hours because only $100 \mathrm{mcg} /$ fentanyl, which is a short acting synthetic analgesic opioid was the only drug given. The study group had additional 4 hours of pain relief due to additive effect of Magnesium sulphate with the fentanyl, thus it helps to prolong the duration of analgesia.

The study done by Gupta et al. ${ }^{4}$ and various other authors describe about the sedation they have acquired from the utilization of Magnesium sulphate and similarly in our study we have also obtained a better sedation profile compared to the control group. Patients in the control groups had more analgesic requirement during the first 24 hours postoperatively, while patients in the Magnesium group had less discomfort during the first 24 hours after the operation. They also had better sleep quality during the first postoperative night than the control group patients. Patients receiving magnesium sulphate were found to be more sedated in immediate postoperative period as compared to control group, although they were easily arousable. This is expected as magnesium is regarded as a CNS depressant. Many studies evaluating. 5 the effect of magnesium sulphate in postoperative analgesia have not measured the postoperative sedation scores. These results are different from the studies where patients receiving magnesium sulphate were not observed to be sedated in spite of using magnesium sulphate as bolus and/or infusion.

It is well known that magnesium may induce hypotension directly by vasodilatation as well as indirectly by sympathetic blockade and inhibition of catecholamine release. However, we did not observe any hypotensive episode in our patients treated with magnesium sulphate. Transient fall in blood pressure was observed in our patients at induction in both groups that can be attributed to use of propofol as an induction agent. None of our patients had a significant bradycardia that required treatment. Sirivinskas. ${ }^{6}$ also have come across a very less number of patients with complications, such as nausea and vomiting. We also noticed that in our study the complications we had encountered was very minimal. ${ }^{7}$

\section{CONCLUSION}

Even though the field of anaesthesia is overwhelming with the boons of pain relieving medications and the procedures, still we lag behind in the field. We have conducted a double blinded randomized case control study in 60 patients divided into two groups and the study group received $50 \mathrm{mg} / \mathrm{kg}$ Magnesium sulphate in $100 \mathrm{~mL}$ of saline 30 minutes before the induction of general anaesthesia the other thirty patients are the control group who receives only $100 \mathrm{~mL}$ of saline. We have come to the following conclusion:

1. Giving Magnesium sulphate as an adjuvant preoperatively considerably doubled the duration of analgesia compared to the control group.

2. The magnesium group showed higher sedation score, but they are arousable on command.

3. Adverse effects like nausea and vomiting were minimal in the study group.

\section{REFERENCES}

1. Kiran S, Gupta R, Verma D. Evaluation of a single dose of intravenous magnesium sulphate for prevention of postoperative pain after inguinal surgery. Indian J Anaesth 2011;55:31-5.

2. Gupta SD, Mitra K, Mukherjee M, et al. Effect of magnesium infusion on thoracic epidural analgesia. Saudi J Anaesth 2011 Mar;36(6):55-8.

3. Dabbagh A, Elyasi H, Razavi SS, et al. Intravenous magnesium sulphate for post-operative pain in patients undergoing lower limb orthopaedic surgery. Acta Anaesthesiol Scand 2009 Sep; 53(8):1088-91.

4. Bhatia A, Kashyap L, Pawar DK, et al. Effect of intraoperative magnesium infusion on perioperative analgesia in open cholecystectomy. J Clin Anaesth 2004 Jun;16(4):262-5.

5. Levaux $\mathrm{CH}$, Bonhomme V, Dewandre PY, et al. Effect of intra-operative Magnesium sulphate on pain relief and patient comfort after major lumbar orthopaedic surgery. Anaesthesia 2003 Feb;58(2):131-5.

6. Sirvinskas E, Laurinaitis R. Use of magnesium sulphate in anaesthesiology. Medicina Lithuanian. Kaunas 2002;38(7):695-8.

7. Telci L, Esen F, Akcora D, et al. Evaluation of effects of magnesium sulphate in reducing intra-operative anaesthetic requirements. Br J Anaesth 2002;89:594-8. 